\title{
Factors influencing the behaviour of academics towards peer-reviewed electronic journals in Zimbabwean state universities
}

\author{
Takawira Machimbidza ${ }^{1}$ and Stephen Mutula ${ }^{2}$ \\ tmachimbidza@gmail.com ORCID: orcid.org/0000-0002-3267-8794 \\ mutulas@ukzn.ac.za ORCID: orcid.org/0000-0003-3776-8104
}

\begin{abstract}
Received: 29 September 2017
Accepted: 27 January 2018

This study investigated the factors influencing the behaviour of academics towards peer-reviewed electronic journals at three state universities in Zimbabwe. The study employed both quantitative and qualitative approaches using a survey research design. Quantitative data were collected through structured questionnaires that were administered to a sample of 363 academics. The response rate was $58.4 \%$. Qualitative data were collected through interviews that were held with nine professional librarians. Results show that barriers and other mitigating factors that negatively affect the behaviour of academics towards peer-reviewed electronic journals include inadequate infrastructure to support access to electronic journals, inefficient and slow speed of internet connections, lack of skills to navigate the electronic journals environment, challenges with off-campus access, user-unfriendly library website interfaces, and difficult-to-use electronic journal interfaces. The study concluded that state universities in Zimbabwe have not done enough to address the challenges that affect usage of electronic journals. The study recommends that universities in Zimbabwe work to eliminate all forms of barriers that discourage use of peer-reviewed electronic journals. They can lobby government for tax exemptions when importing equipment for use in electronic journals access. The private sector can also be encouraged to play a part in supporting the building of electronic journals infrastructure. Training of new academic members of staff in the access of electronic journals should be made mandatory, and refresher training instituted for previously trained academics.
\end{abstract}

Keywords: Academics, facilitating conditions, peer-reviewed electronic journals, Zimbabwe State Universities, Zimbabwe University Libraries Consortium

\section{Introduction}

The emergence of peer-reviewed electronic journals in academia at the close of the twentieth century marked a new milestone for research and scholarship that presented academics and students in universities with expanded opportunities for timely access to information. Journal publishers saw in electronic journals an opportunity to lower costs through reduction or elimination of printing and distribution charges (Curtis 2005, Greenberg 2015). In addition, electronic journals allowed publishers to expand their audience by reaching out to researchers in institutions all over the world without the limitation of physical borders and distance (Cox and Cox 2010). University libraries that were affected by the ever-increasing costs of print publications quickly welcomed the shift in emphasis from ownership to access. This move reduced costs and broadened the resource base for their clients, chiefly academics and students (Ambedkar 2017).

University libraries in Zimbabwe responded to the opportunity presented by the peer-reviewed electronic journals initiative by organising themselves into the Zimbabwe University Libraries Consortium (ZULC). The main goal of ZULC is to alleviate shortage of reading resources and increase access to scholarly information in member institutions. In 2003, ZULC managed to negotiate access to over 18,000 full text and 7,000 abstract peer-reviewed electronic journals through the International Network for the Availability of Scientific Publications (INASP) Programme for the Enhancement of Research Information (PERI) initiative (Asamoah-Hassan et al. 2005). This initiative provides expensive academic journals online to institutions in developing countries at cheaper or affordable prices (Asamoah-Hassan et al. 2005). In addition to the PERI initiative, university libraries in Zimbabwe benefitted from other initiatives. For example, the World Health Organisation (WHO), Food and Agricultural Organisation (FAO) and the United Nations Environment Programme (UNEP) spearheaded the provision of information on health sciences, agricultural sciences, and environmental sciences, respectively, through electronic journal databases. The databases included Health Inter-Network Access to Research Initiative (HINARI), Access to Global Online Research in Agriculture (AGORA), and Online Access to Research in the

1. Takawira Machimbidza is a postdoctoral fellow in the Information Studies Programme, University of KwaZulu-Natal, South Africa

2. Stephen Mutula is Professor in the Information Studies Programme and is Acting Deputy Vice-Chancellor: College of Humanities, University of KwaZulu-Natal, South Africa 
Environment (OARE) (FAO 2008). Another initiative, Electronic Information for Libraries (EIFL), has also provided electronic journals to university libraries in Zimbabwe.

The initiative by ZULC was expected to bring major relief to the academic community in Zimbabwean state universities as it came on the back of declining government funding that had negatively affected the purchase of books and print journals. Universities depended more on donations, many of which were not suitable for academic purposes (INASP 2006). University libraries in Zimbabwe expected electronic journals easily to gain traction with the academic community as the resources addressed its long-expressed needs for increased choice of information, timeliness and convenience. However, contrary to expectations, and despite several efforts made by ZULC and individual university libraries in Zimbabwe to enhance access to peer-reviewed electronic journals, the use of such journals among academics remains minimal. The statistics ZULC harvests from providers of peer-reviewed electronic journals show low usage many years after introduction of these resources. Academics in Zimbabwe have been singled out for their failure to provide leadership in the use of peerreviewed electronic journals (Tsvere, Nyaruwata and Swamy 2013, Machimbidza 2014, Madondo, Sithole and Chisita 2017). The underutilisation of peer-reviewed electronic journals by academics in Zimbabwe is against the backdrop of the increasing cost of subscribing to these resources (Veeramani and Vinayagamoorthy 2010, Shahmohammadi 2012). The arrangement that ZULC has with journal providers, where affiliate universities subscribe to selected electronic journals at discounted rates, has not insulated institutions from increasing costs. In the face of minimal usage, justifying these costs to university administrators is a difficult task. The libraries run the risk of having their electronic journals subscription budgets cut since usage statistics are not commensurate with the cost incurred in maintaining subscriptions to these resources.

Since the introduction of peer-reviewed electronic journals into the academic world, researchers from different countries have sought to understand their adoption and use. They have been trying to establish why university communities, especially in Africa, have not embraced use of the electronic resources as expected. Findings have varied and have included issues of awareness (Bayugo and Agbeko 2007, Dilek-Kayaoglu 2008, Khan and Ahmad 2009, Salaam and Aderibidge 2010, Shahmohammadi 2012), attitudes and perceptions (De Groote 2008, Salaam and Aderibidge 2010, Tyagi 2012), promotion (Thanuskodi 2011, Vasishta and Navivoti 2011), and facilitating conditions as factors that influence the use of these resources (Ondari-Okemwa 2004, Bevilacqua 2005, Upadhyay and Chakraborty 2008, Salaam and Aderibidge 2010, Shahmohammadi 2012). Among the factors affecting electronic journals usage in universities, the issue of facilitating conditions has been prominent, especially in the context of developing countries. Facilitating conditions are known to influence the behaviour of users concerning the use of electronic journals. The theories of Planned Behaviour (TPB) (Ajzen 1991, Taylor and Todd 1995), Diffusion of Innovation (DOI) (Moore and Benbasat 1991, Orr 2003, Rogers 2003) and Unified Theory of Acceptance and Use of Technology (UTAUT) (Venkatesh et al. 2003) have all identified facilitating conditions as a major factor influencing the use of electronic resources. Other factors influencing the behaviour of users towards electronic journals include infrastructure to support access, efficiency and speed of internet connection, skills to navigate the electronic environment, availability of off-campus access, user-friendliness of university libraries' website interfaces and specific journal interfaces (Ondari-Okemwa 2004, Bevilacqua 2005, Upadhyay and Chakraborty 2008, Salaam and Aderibidge 2010, Shahmohammadi 2012).

Studies that have investigated the factors influencing the behaviour of academics towards peer-reviewed electronic journals have focused on developed countries of North America, Europe, and some parts of Asia and the Middle East. Only a few countries in Africa (Nigeria, Uganda, Kenya, Tanzania, Malawi, Ethiopia, Ghana and South Africa) have visible literature on the subject (Dadzie 2005, Ani and Ahiauzu 2008, Manda 2008, Harle 2010, Egberongbe 2011). Zimbabwe is among other countries in Africa that have not yet conducted notable research in this area: there are only a few published studies that cover factors influencing the behaviour of academics toward peer-reviewed electronic journals, despite the fact that state universities started offering them in 2003 (Machimbidza 2014). An investigation of the factors that influence the behaviour of academics towards peer-reviewed electronic journals in the Zimbabwean context would therefore provide university librarians, policy makers and organisations offering electronic resources with information on the key barriers affecting usage of these resources. The research may result in corrective action that could benefit wider university communities in Zimbabwe.

\section{Purpose of the study}

The study investigated the factors (facilitating conditions) influencing the behaviour of academics towards peer-reviewed electronic journals at three state universities in Zimbabwe. The objectives of the study were to:

- establish the extent to which academics consider technological infrastructure in their institutions adequate to support access to peer-reviewed electronic journals;

- determine if the efficiency and speed of internet connectivity in Zimbabwean state universities is conducive for unhindered use of electronic journals; 
- $\quad$ find out the extent to which academics possess the skills necessary to navigate the electronic environment;

- $\quad$ examine the accessibility of peer-reviewed electronic journals off-campus; and,

- $\quad$ establish the user-friendliness of university libraries' website interfaces and specific journal interfaces.

\section{Literature review}

Literature and technology adoption theories argue that, for an innovation to be adopted and used, there should be 'facilitating conditions'. These are conditions that make it easier for the intended user to adopt and use a given technology (Ajzen 1991, Taylor and Todd 1995, Rogers 2003, Venkatesh et al. 2003). Absence of these conditions constitutes 'barriers' to use. Electronic journals have been readily accepted in countries and institutions where barriers to access and use are minimal. In contrast, electronic journals have not been readily accepted in situations where users are faced with barriers (Salaam and Aderibidge 2010, Shahmohammadi 2012). Several African scholars agree that one of the major hindrances to the adoption and use of electronic resources on the continent is lack of the requisite infrastructure. Harle (2010) noted that the advent of electronic journals came as a blessing to the continent. It meant, at last, that African scholars could access rich resources stored on developed world servers. This move, however, came with its challenges as institutions needed to upgrade their Information and Communications Technology (ICT) facilities and infrastructure such as computers, telecommunications technologies, internet, bandwidth, power supply, as well as peripheral technologies like printers, copiers, and scanners (Stanford University Libraries 2001). In addition, institutions must ensure they have adequate institutional contracts and licenses with publishers and other libraries in order to have rights to access electronic journals. There is also a need to engage adequately-skilled administrative and support personnel. Manda (2008) noted that African institutions have largely been affected by inadequate information infrastructure and the absence of basic facilities required to access electronic resources effectively and efficiently. Manda (2008) further noted that, while many African universities have at last managed to improve academics' levels of access to computers connected to the internet with the ratio almost $1: 1$, one major infrastructural constraint is limited bandwidth which causes slow and dropped connections, and, when downloading journals, data packets are frequently lost and files corrupted. Shija (2009) identified the same bandwidth problem in the context of institutions in Tanzania. It is refreshing, however, that the latest research by Pima et al. (2016) suggested there has been improvement in bandwidth and other technologies in Tanzanian institutions of higher learning.

Elsewhere in Africa, Watts and Ibegbulam (2006) examined some of the barriers to the usage of electronic information resources available at the medical library of the College of Medicine, University of Nigeria, Nsukka. Their findings revealed that lack of an adequate ICT infrastructure posed a problem to the access and use of these resources. At Jomo Kenyatta University of Agriculture and Technology in Kenya, the use of electronic journals was also hampered by lack of infrastructure. This meant that, despite the marketing of electronic resources, they were still not used optimally (Gikandi and Ndungu 2011). The university provided a wireless network with many hotspots scattered across the university, however users were often frustrated by low bandwidth. At the University of Agriculture in Abeokuta, Nigeria, the main constraint to the use of electronic journals is the unstable supply of electricity. The problem of poor electricity supply was also reported by Owolabi and Agboola (2010) as the biggest problem affecting the use of ICT facilities in many African institutions. Respondents in another Kenyan study identified the following challenges that were experienced in accessing electronic resources: inadequate computers, poor internet connectivity, delays in downloading information, and lack of support facilities such as printers (Gathoni et al. 2011). The Kenyan study recommended that efforts be made towards upgrading and increasing the existing infrastructure including computers, internet bandwidth and skilled staff.

Infrastructural capabilities improved in some African countries post-2010. Harle (2010) observed that internet connectivity, particularly in some east African universities is steadily improving with the installation, in 2009 and 2010, of three new high-speed undersea fibre-optic cables. However, outside major cities and from coastal countries to landlocked countries, substantial infrastructural challenges remain. The use of electronic journals has continued to be low in those countries and cities where internet connection is poor. The value of adequate infrastructural support in the adoption and use of electronic resources can be seen from a study in Iran. In a study that covered 232 social science academics in seven Iranian universities (Ran University, Shiraz University, Ahvaz University, Karman University, Esfahan University, Tehran University and Mashhad University), it was reported that academics were dependent on electronic resources. However, social science academics in Iran were afforded adequate infrastructure to enable them to access and use electronic journals. For example, they were provided with computers and internet facilities. Furthermore, they were provided with free internet connections at their residences through their universities, and campuses were Wi-Fi enabled (Negahban and Talawar 2009).

The adoption and use of electronic journals particularly in Africa has also been hampered by lack of skills to negotiate the electronic environment. Borah et al. (2004) complain about what they call the "access paradox" syndrome, where an increasing amount of information is increasingly being made available in electronic format, but that users are unable to find it because they lack the necessary skills. They advise that users should be able to construct effective search strategies, 
critically appraise information sources, use information sources appropriately, and cite and create references. OndariOkemwa (2004), Ashcroft and Watts (2005), and Oduwole and Sowole (2006) identified problems in the adoption and use of electronic resources in Nigeria. The main problem identified was the lack of adequate ICT skills among academics. Shija (2009) noted that, for someone to access and use electronic journals effectively and efficiently, there is a need for a good command of skills to use a computer and the internet. He noted that skills were still inadequate in Africa and advised that training was necessary to enable academics to benefit from the electronic resources at their disposal. He alleged that the problem of lack of ICT skills in Africa has not yet been seriously addressed. Some institutions offer once-off training workshops to researchers while others offer no training at all. Shija's (2009) findings resonate with the findings of Manda (2008) who carried out an extensive study of twenty-three institutions of higher education in Tanzania. Only $41 \%$ of the institutions reported that they had trained their users in the use of electronic resources. The reasons given for lack of training in many of these institutions included inadequate skills on the part of the library staff, a lack of interest by academics or a heavy workload which deprived academics of time to attend formal training. The methods of training in these institutions seemed inadequate as training was mainly conducted through short seminars and workshops, or informally where users were requested to register for training on a voluntary basis.

\section{Methodology}

This study employed both quantitative and qualitative approaches using a survey research design. Quantitative data were collected through structured questionnaires that were administered to a sample of 363 academics from three state universities in Zimbabwe, namely Bindura University of Science Education (BUSE), National University of Science and Technology (NUST) and Midlands State University (MSU). These universities were chosen from a pool of eleven state universities that are currently operational in Zimbabwe. The three were chosen because they are three of the biggest in terms of the number of academics and students. They are also the oldest state universities in Zimbabwe and have been offering access to peer-reviewed electronic journals for some time. The three universities were also suitable because they offer a variety of disciplines, a feature which was critical in preventing discipline bias in the results of the study. Permission to study these universities was obtained from the universities' respective registrars. The sample size for academics was determined through a sampling framework developed by Bartllett, Kotrlik and Higgins (2001). This framework, which assumes a margin of error of 0.05 or $5 \%$, dictates that for a population of 800 , the sample size should be 363 . The total population of academics in the three universities is 794 . This figure was rounded up to 800 so that it fits within the sampling framework. Since the respondents came from different universities, the number targeted at each university was decided upon on a proportional basis as follows: the number of academics at each university divided by the total number of academics in the three universities multiplied by the sample size. This produced sample sizes for the three universities as shown in Table 1:

Table 1 Sample sizes applied to the three universities in respect of academics

\begin{tabular}{lcccc}
\hline & University A & University B & University C & Total \\
\hline Population & 302 & 180 & 312 & $\mathbf{7 9 4}$ \\
Sample size & 138 & 82 & 143 & $\mathbf{3 6 3}$ \\
\hline
\end{tabular}

Qualitative data were collected through interviews that were held with nine professional librarians from the same universities. From each of the three universities, interviews were held with the Librarian, the Sub-Librarian ${ }^{3}$ responsible for Reader Services, and the Systems Librarian. Each interview session averaged fifteen to twenty minutes. The response rate for academics was $58.4 \%$ as 212 questionnaires were returned out of the 363 that were distributed. Of the returned questionnaires 193 were deemed usable for this study (University A - 69, University B - 44, and University C - 80). Quantitative data were analysed using the Statistical Package for Social Sciences (SPSS) version 19 while thematic analysis was applied for qualitative data.

\section{Results and Discussion}

The results of the study are organised according to objectives.

3. In the context of Zimbabwean university libraries, the Sub-Librarian position is the position immediately below the Deputy Librarian. SubLibrarians are heads of departments (such as Reader Services) while Assistant Librarians head specific sections within departments and also function as Faculty Librarians. 


\subsection{Infrastructure to support access to electronic journals}

Academics were asked if their institutions had adequate infrastructure and resources such as desktop computers, laptops, computer laboratories and related facilities to allow unrestricted access to electronic journals. About $46.6 \%$ (ninety) of academics agreed that infrastructure was in place, 13.5\% (twenty-six) were neutral and $39.9 \%$ (seventy-seven) were not happy with the infrastructural investments their institutions had made. In responding to a supporting question, 38.3\% (seventy-four) of academics indicated that infrastructure was a major barrier to their use of electronic journals. About $50.8 \%$ (ninety-eight) indicated that infrastructure was a minor barrier, but nevertheless a barrier. Only $10.9 \%$ (twenty-one) indicated that the issue of infrastructure and resources did not pose a barrier to their use of electronic journals. About $22.3 \%$ (fortythree) of academics indicated they had problems accessing a computer to enable the use of electronic journals. Additionally, $32.1 \%$ (sixty-two) indicated they had unlimited access to computers and $45.6 \%$ (eighty-eight) reported that they had limited, mostly shared, access to computers.

University $\mathrm{C}$ appeared the most prepared with regard to internet infrastructure among the three universities surveyed. About $78.7 \%$ (sixty-three) academics at the institution agreed that their institution had adequate resources to enable unrestricted access to electronic journals. Only $6.3 \%$ (five) of academics disagreed while $15 \%$ (twelve) chose to be neutral. At University A, 59.6\% (forty-one) of academics disagreed with the view that their institution had adequate resources. About $28.9 \%$ (twenty) agreed that they had the resources they needed while $11.5 \%$ (eight) chose to be neutral. At University B, $70.5 \%$ (thirty-one) disagreed. Furthermore, $15.9 \%$ (seven) of academics at University B felt they had the resources they needed to access electronic journals while $13.6 \%$ (six) chose to be neutral. The statistics regarding adequacy of infrastructure per university are summarised in Table 2.

Table 2: Adequacy of infrastructure to support access to electronic journals per university

\begin{tabular}{lcccc}
\hline Response & University A & University B & University C & Total \\
\hline Disagree & $41(59.6 \%)$ & $31(70.5 \%)$ & $5(6.3 \%)$ & 77 \\
Neutral & $8(11.5 \%)$ & $6(13.6 \%)$ & $12(15 \%)$ & 26 \\
Agree & $20(28.9 \%)$ & $7(15.9 \%)$ & $63(78.7 \%)$ & 90 \\
Total & $\mathbf{6 9 ( 1 0 0 \% )}$ & $\mathbf{4 4 ( 1 0 0 \% )}$ & $\mathbf{8 0 ( 1 0 0 \% )}$ & $\mathbf{1 9 3}$ \\
\hline
\end{tabular}

Professional librarians in the three universities confirmed the feelings of academics in their institutions. The Librarian for University C, an institution whose academics were mostly happy with resources at their disposal, stated,

Our institution has invested heavily in computer laboratories and the attendant technologies. Most of our users have the infrastructure they need to access electronic resources.

At University A, the Librarian indicated that the university had challenges with resources and infrastructure, but urged academics to maximise what was available. The Sub-Librarian for Reader Services at University A opined that the university had tried to provide the necessary resources within the constraints of economic conditions. The Systems Librarian at University A complained about the lack of laptops for academics' use. This, he argued, "impacted negatively on off-campus access". At University B, both the Librarian and Sub-Librarian for Reader Services indicated that they were not happy with the infrastructure for electronic journals access at the institution. They, however, indicated that some initiatives were in the pipeline to ease the situation. They also highlighted that academics were being encouraged to buy laptops and tablets from private companies at favourable rates negotiated by the university. The results of this objective, particularly about the infrastructural conditions of University A and University B, concur with the findings of other researchers who studied institutions in Africa. These include Watts and Ibegbulam (2006), Manda (2008), Shija (2009), Harle (2010), and Owolabi and Agboola (2010). These researchers agreed that financial constraints have undermined the efforts of institutions in Africa. While they may negotiate access from the providers of electronic journals, they struggle to upgrade their own infrastructure because of limited funding.

\subsection{Efficiency and speed of internet connection}

Closely related to the issue of availability of resources to accessing electronic journals dealt with above is efficiency and speed of internet connection. About $51.8 \%$ (100) of academics indicated that they were frustrated by erratic and unreliable internet connection. Academics, especially from University A and University B, noted that their internet had long periods of downtime, an issue that frustrated their use of the resources. About $76.8 \%$ (fifty-three) of academics at University A felt internet unreliability was a major factor negatively impacting their use of electronic journals, $18.9 \%$ (thirteen) pointed to the issue of internet connectivity as a minor barrier, while only $4.3 \%$ (three) said internet connectivity did not constitute a barrier to their use of electronic journals. At University B, $90.9 \%$ (forty) of academics indicated that internet unreliability was a major barrier to their efforts to use electronic journals, $6.8 \%$ (three) cited the issue of internet connectivity as a minor barrier while 
only one respondent was not affected by internet connectivity. Academics at University C were satisfied with the service, with only $8.6 \%$ (seven) of them citing internet connectivity as a major barrier, $71.4 \%$ (fifty-seven) stated that it was a minor barrier, and $20 \%$ (sixteen) indicated that it was not a barrier at all. Professional librarians at University A and University B complained more about electricity cuts that affected their ability to provide a reliable service. Librarians at University A noted that only the Faculty of Medicine was spared the cuts since it was housed within a hospital which is exempt from electricity cuts, being a health institution. The standby generators installed at the university do not cover the whole university. At University B, the librarians indicated that the problem of electricity cuts severely affected those academics based at their satellite campuses. Academics based at the main campus were assisted by standby generators. At University $\mathrm{C}$, the librarians reported that load shedding did not affect use of electronic journals as the institution invested in generators that cover all faculties and computer centres.

Data from the questionnaire showed that academics were also concerned about internet speed. The majority complained of low bandwidth which caused slow download speeds. About $63.2 \%$ (122) of academics complained of slow download speeds and noted that this was a major hindrance to their use of electronic journals. Academics at University A and University B were concerned about speed, whereas those at University C were satisfied. About $65 \%$ (fifty-two) of academics at University $C$ expressed satisfaction with the speed of the internet at their institution. At University $A$ and University B only $23.2 \%$ (sixteen) and $6.8 \%$ (three), respectively, were satisfied with download speeds. In the interviews, professional librarians from the three institutions seemed to agree with their academic staff. The Sub-Librarian for Reader Services and the Systems Librarian at University A reported that their internet was slow owing to low bandwidth which stood at $160 \mathrm{Mbps}$. Considering the number of internet users at University A, this amount of bandwidth is inadequate and causes slow download speeds. To increase bandwidth, funds, which were not available, were needed. At University B, both the Sub-Librarian for Reader Services and the Systems Librarian were concerned about the internet speed, though they noted efforts were being made to upgrade the bandwidth. Bandwidth at University B stood at $32 \mathrm{Mbps}$, far lower than the other two institutions in this study. At University $\mathrm{C}$, the professional librarians were very happy with the bandwidth. The Librarian indicated the university was operating on a bandwidth of $200 \mathrm{Mbps}$.

The unreliability of internet connection and low bandwidth cited by academics and professional librarians at University $A$ and University B respectively mirror the frustrations of other academics and librarians in African institutions. Watts and Ibegbulam (2006), Shija (2009), Harle (2010), and Gikandi and Ndungu (2011) conducted studies in Nigeria, Tanzania, Malawi, and Kenya respectively and concluded that the use of electronic journals was still undermined by erratic internet connections and slow download speeds owing to low bandwidth. Harle (2010), however, noted that the situation is different in South African institutions, where these challenges have largely been addressed.

\subsection{Skills to access electronic journals}

The use of electronic journals is greatly affected by the level of skills of the target users. The researchers sought to establish whether academics had the necessary skills to use electronic journals. Academics were asked to rank themselves accordingly. The results represented in Table 3 show that most academics perceived they had low to average skills when it came to using electronic journals. The results show that only $39.3 \%$ (seventy-six) of academics reported high skills. Responses from supporting questions show that only $30.1 \%$ (fifty-eight) of academics did not consider lack of skills to be a barrier to their use of electronic journals, whereas $69.9 \%$ (135) reported that their skills level was a barrier. About $69.4 \%$ (134) of academics reported that they needed training to improve their skills. Another $30.6 \%$ (fifty-nine) indicated that they did not need any further skills development to access the resources. When the level of skills was considered per university, the results show that academics at University A were the most confident users. About $47.8 \%$ (thirty-three) of them reported high level of skills. At University C and University B, the academics who reported high skills stood at $35 \%$ (twenty-eight) and $34.1 \%$ (fifteen) respectively.

Table 3 Level of skills of academics in the use of electronic journals

\begin{tabular}{lcc}
\hline Ranking & Frequency & Percent \\
\hline Low & 31 & 16.1 \\
Average & 86 & 44.6 \\
High & 76 & 39.3 \\
Total & $\mathbf{1 9 3}$ & $\mathbf{1 0 0}$ \\
\hline
\end{tabular}

Researchers such as Ondari-Okemwa (2004), Oduwole and Sowole (2006), Manda (2008), and Shija (2009) have all highlighted the issue of lack of skills as a major hindrance to the use of electronic journals in African institutions. While the results of this study seem encouraging, the high number of academics who indicated they still need further training suggests 
that some of the academics who ranked themselves in the average and high skills categories still experience a gap that needs to be addressed through further training.

\subsection{Accessibility of resources off-campus}

Some academics indicated that they experienced challenges accessing electronic journals when they were off-campus. About $13.5 \%$ (twenty-six) of academics cited this as a major barrier, $55.4 \%$ (107) cited it as a minor barrier, and $31.1 \%$ (sixty) indicated that this was not a barrier. These results mirror those of researchers such as Bevilacqua (2005), Salaam and Aderibidge (2010) and Shahmohammadi (2012) who reported that the issue of off-campus accessibility is still a concern, especially in developing country universities. Academics from University A and University B complained about challenges with off-campus access more than those from University C. At University A, 21.8\% (fifteen) cited challenges with off-campus access as a major barrier to their use of electronic journals. About $15.9 \%$ (seven) of academics at University B had a similar complaint while 5\% (four) had the same complaint at University C. The Sub-Librarian for Reader Services at University A and the Systems Librarian claimed that these challenges were mostly self-inflicted. They noted that academics who failed to access the resources off-campus were those who had overdue books in their library accounts and unpaid fines for returning library books after due dates; the system was configured to reject access to such users. The two were, however, unsure if academics were aware of this rule. At University B, the Systems Librarian reported major challenges with the offcampus access facility. At University C, the Librarian reported that the off-campus access system worked well.

\subsection{User-friendliness of library website interfaces and specific journals interfaces}

The user-friendliness of the library websites comes into question insofar as access and use of electronic journals is concerned (Chowdhury 2004). Only $41.4 \%$ (eighty) of academics felt their library website interfaces were easy with which to work. The rest faced challenges with library interfaces. About $36.2 \%$ (twenty-five) of academics at University A reported that the library website interface was difficult to negotiate, $30.4 \%$ (twenty-one) of academics chose to be neutral, while $33.4 \%$ (twenty-three) said the interface was easily negotiable. At University B, only $13.6 \%$ (six) felt their library website interface was easily negotiable while $43.2 \%$ (nineteen) thought the interface was difficult to negotiate. An equal percentage was neutral. At University C, $63.8 \%$ (fifty-one) of academics felt their library website interface was easy to negotiate while $11.3 \%$ (nine) felt it was difficult and $24.9 \%$ (twenty) chose to be neutral. Academics seemed to have challenges with interfaces of certain databases. They used databases with which they were comfortable and whose interfaces they could easily navigate. Professional librarians reported that academics were more comfortable with databases such as Emerald Insight, AGORA, HINARI, and EBSCOhost. These databases, professional librarians argued, were easy to use. Researchers such as Shahmohammadi (2012) and Machimbidza (2014) noted that complex library website interfaces and journal interfaces hamper accessibility of electronic resources. It is important that these interfaces are simplified and the navigation skills of users enhanced in order to improve access and use.

\section{Conclusions and Recommendations}

The study concludes that the behaviour of academics towards peer-reviewed electronic journals at the selected state universities in Zimbabwe is negatively affected by the barriers with which they must contend in their quest to use these resources. These barriers and factors include inadequate infrastructure to support access to electronic journals, inefficient and slow speed of internet connection, the lack of skills to negotiate the electronic journals environment, challenges with off-campus access, user-unfriendly library website interfaces, and difficult-to-use electronic journal interfaces. These debilitating factors affect academics in different Zimbabwean institutions to different degrees. The academics at University C were in a better position than their counterparts at University A and University B. Overall, however, state universities in Zimbabwe have not done enough to eliminate the challenges that discourage usage of electronic journals.

The study recommends that universities in Zimbabwe work to eliminate all forms of barriers that mitigate against the use of peer-reviewed electronic journals in the country. Creative solutions should be employed to deal with the scourge of lack of infrastructure and equipment. Every academic should be afforded a computer to use in accessing the resources and not have to rely on shared access. Bandwidth should be improved, printers should be acquired to support those academics who want to print their findings, and off-campus access should be enhanced. Admittedly, these issues require funding of which universities in Zimbabwe are mostly starved. However, creative solutions can be found. For a start, universities can lobby the government for tax exemptions when they import crucial equipment such as that used to enable access to electronic journals. This will significantly reduce the cost of acquiring equipment and the cost of building an infrastructural base to support access to peer-reviewed electronic journals. Universities can also court help from the private sector, then negotiate with government to have the participating organisations enjoy tax rebates for the amounts used to acquire equipment and other infrastructure for universities. The training for new academic hires should be made mandatory; it should form part of their contracts. The cooperation of registrars, deans of faculties, and chairpersons of departments is 
important to achieve this. Librarians should also consider making the training of academics in the use of electronic journals an ongoing process as journal interfaces change and new skills are demanded of users, even those previously trained. To encourage academics to respond to training, university policy should make it mandatory for academics to include electronic journals in their course outlines. University Librarians need to lobby their respective university senates for such a policy.

\section{References}

Ajzen, I. 1991. The theory of planned behaviour. Organisational Behaviour and Human Decision Processes, 50: $179-211$.

Ambedkar, B. R. 2017. Changing face of scholarly communication and its impact on library and information centres. In Scholarly communication and the publish or perish pressures of academia. A. Munigal, Ed. Hershey PA: IGI Global.

Ani, O. E. and Ahiauzu, B. 2008. Towards effective development of electronic information resources in Nigerian University Libraries. Library Management, 29(6/7): 504-514.

Asamoah-Hassan, H., Ballantyne, P., Gwynn, S., Manda, P. and Winder, D. 2005. Enhancing access to research information in developing countries: report from a mid-term review of the Programme for the Enhancement of Research Information (PERI). Oxford: INASP, January 2005. [Online]. http://www.inasp.info/uploads/filer_public/2013/04/09/peri_evaluation_2001-2004.pdf (07 February 2018).

Ashcroft, L. and Watts, C. 2005. ICT skills for information professionals in developing countries: perspectives from a study of the electronic environment in Nigeria. IFLA Journal, 31(1): 6-12.

Bartllett, J. E., Kotrik, J. W. and Higgins, C. C. 2001. Organisational research: determining appropriate sample size in survey research. Information Technology, Learning, and Performance Journal, 19(1): Spring 2001. [Online]. http://www.osra.org/itpj/bartlettkotrlikhiggins.pdf (15 March 2012).

Bayugo, S. S. and Agbeko, K. S. 2007. Information seeking behavior of health sciences faculty at the College of Health Sciences, University of Ghana. Information Development, 23(1): 63-70.

Bevilacqua, F. 2005. Organising e-journals from the point of view of humanities: a case study at the University of Parma. New Library World, 106(9): 416-429. [Online]. DOI:10.1108/03074800510623092 (16 July 2015).

Borah, E., Kuchida, H., Lee, D., Lippincott, A. and Nagaraj, S. 2004. Access paradox: an information literacy campaign response. Paper presented at the eLit 2004 Conference. 1-3 June 2004. [Online]. http://www.elitconf.org/elit2004/docs/sess3rmb3.htm/ (24 June 2016).

Chowdhury, G. 2004. Access and usability issues of scholarly electronic publications. In: Scholarly publishing in an electronic era. International Yearbook of Library and Information Management. London: Facet Publishing [Online]. https://pure.strath.ac.uk/portal/files/157124/strathprints002606.pdf (7 September 2017).

Cox, J. and Cox, L. 2010. E-only scholarly journals: overcoming the barriers. [Online]. http://www.rin.ac.uk/transitionsschool-comms (4 March 2016).

Curtis, D. 2005. E-journals: a how-to-do-it manual for building, managing, and supporting electronic journal collections. London: Facet Publishing.

Dadzie, P. S. 2005. Electronic resources: access and usage at Asheshi University College. Campus-Wide Information Systems, 22(5). [Online]. http://www.emeraldinsight.com (16 February 2015).

De Groote, S. L. 2008. Citation patterns of online and print journals in the digital age. Journal of the Medical Library Association, 96: 362-369.

Dilek-Kayaoglu, H. 2008. Use of electronic journals by faculty at Istanbul University, Turkey: the results of a survey. Journal of Academic Librarianship, 34(4): 239-247.

Egberongbe, H. S. 2011. The use and impact of electronic resources at the University of Lagos. Library Philosophy and Practice, Paper 472. [Online]. http://digitalcommons.unl.edu/libphilprac/472 (6 February 2015).

Food and Agriculture Organisation of the United Nations (FAO). 2008. AGORA: Access to global online research in agriculture. [Online]. http://www.agInternetwork.org/en/ (19 February 2014).

Gathoni, N., Gikandi, J., Ratanga, F., Njoroge, E. M., Wasike, E., Kiilu, D. and Kabugu, A. 2011. Monitoring and evaluation of electronic resources in academic and research institutions in Kenya: summary report. [Online]. http://www.inasp.info/uploads/filer_public/2013/04/09/monitoring_and_evaluation_of_eresources_in_ke_summary_report.pdf (07 February 2018).

Gikandi, J. and Ndungu, M. 2011. E-resources promotional activities at Jomo Kenyatta University of Agriculture and Technology (JKUAT). [Online]. http://www.inasp.info/media/www/documents/2011-OA-KE-JKUAT-report.pdf (07 June 2016).

Greenberg, M. I. 2015. Open access publishing in higher education: charting the challenging course to academic and financial sustainability. Journal of Educational Controversy, 10(1): Article 5. [Online]. https://cedar.wwu.edu/jec/vol10/iss1/5 (23 January 2018).

Harle, J. 2010. Growing knowledge: access to research in east and southern African universities. London: The Association of Commonwealth Universities.

International Network for the Availability of Scientific Publications (INASP). 2006. Proceedings of the Monitoring and Evaluation of E-Resources Use (MEERU) Workshop; 26-28 September 2006; University of Zimbabwe Law Library, Zimbabwe.

Khan, A. M. and Ahmad, N. 2009. Use of e-journals by research scholars at Aligarh Muslim University and Banaras Hindu University. The Electronic Library, 27(4): 708-717. DOI:10.1108/02640470910979642 (13 August 2016). 
Machimbidza, T. 2014. The adoption and use of peer reviewed electronic journals by academics at selected Zimbabwean state universities. PhD thesis. University of KwaZulu-Natal. [Online].

https://researchspace.ukzn.ac.za/bitstream/handle/10413/12120/Machimbidza_Takawira_2014.pdf?sequence=1\&isA llowed=y (23 January 2018).

Madondo, T., Sithole, N. and Chisita, C. T. 2017. Use of electronic information resources by undergraduate students in the Faculty of Management and Administration at Africa University, Mutare, Zimbabwe. Asian Research Journal of Arts and Social Sciences, 2(2): 1-12.

Manda, P. A. 2008. Access to electronic library resources and services in academic and research institutions in Tanzania. In Evaluating electronic resource programme and provision: Case studies from Africa and Asia. D. Rosenberg, Ed. INASP Research and Education Case Studies, No. 3. Oxford: INASP.

Moore, G. C. and Benbasat, I. 1991. Development of an instrument to measure the perceptions of adopting an information technology innovation. Information Systems Research, 2 (3), 192-222.

Negahban, M. B. and Talawar, V. G. 2009. Dependency on e-resources among social science faculty in Iranian Universities. Chinese Librarianship: an International Electronic Journal, 28. [Online]. http://www.iclc.us/cliej/c128NT.htm (18 June 2016).

Oduwole, A. A. and Sowole, A. O. 2006. Utilisation and impact of The Essential Electronic Agricultural Database (TEEAL) on library services in the Nigerian University of Agriculture programme. Electronic Library and Information Systems, 40(2): 157-167.

Ondari-Okemwa, E. 2004. Impediments to promoting access to global knowledge in sub-Saharan Africa. Library Management, 25(8/9): 361-375.

Orr, G. 2003. Review: Diffusion of Innovations, by Everett Rogers (1995). [Online]. http://www.stanford.edu/class/symbsys205/Diffusion\%20of\%20Innovations.htm (22 January 2016).

Owolabi, K. A. and Agboola, O. I. 2010. Internet access and usage by academic staff of University of Agriculture in Nigeria. International Journal of Information and Communication Technology, 17(1): 45-51.

Pima, J. M., Odetayo, M., lqbal, R. and Sedoyeka, E. 2016. Assessing the available ICT infrastructure for collaborative web technologies in a blended learning environment in Tanzania: a mixed methods research. International Journal of Education and Development using Information and Communication Technology (IJEDICT), 12(1): 37-52. [Online]. https://files.eric.ed.gov/fulltext/EJ1099579.pdf (23 January 2018).

Rogers, E. M. 2003. Diffusion of innovations. $5^{\text {th }}$ ed. New York: Free Press.

Salaam, M. O. and Aderibidge, N. A. 2010. Awareness and utilisation of The Essential Electronic Agricultural Library (TEEAL) by academic staff: a case study of University of Agriculture, Abeokuta, Nigeria. Chinese Librarianship: an International Electronic Journal, 30. [Online]. http://www.iclc.us/cliej/c1305A.pdf (10 August 2016).

Shahmohammadi, N. 2012. Online electronic journals use among university academic faculty members of Islamic Azad University, Karaj Branch. Asian Journal of Natural and Applied Sciences, 1(1). [Online]. http://www.ajsc.leenaluna.co.jp/AJSCPDFs/Vol.1(1)/AJSC2012(1.1-03).pdf (23 July 2015).

Shija, H. 2009. E-resources use via the internet improvement is a must: a case of special libraries in Tanzania. Research on Poverty Alleviation (REPOA). Dar es Salaam, Tanzania. [Online]. http://www.ais.up.ac.za/digi/docs/shija_paper.pdf (16 August 2014).

Stanford University Libraries. 2001. E-journal usage and scholarly practice: an ethnographic perspective on the role and impact of e-journal usage among users of biomedical literature. [Online]. http://ejust.stanford.edu/findings/full_0801.pdf (13 June 2014).

Taylor, S. and Todd, P. A. 1995. Understanding information technology usage: a test of competing models. Information Systems Research, 6(2): 144-176.

Thanuskodi, S. 2011. User awareness and use of e-journals among education faculty members in Chennai: a survey. International Research: Journal of Library and Information Science, 1(1). [Online]. http://irjlis.com/pdf_V1N1_jun_2011//R006.pdf (28 May 2015).

Tsvere, M., Nyaruwata, T. L. and Swamy, M. 2013. Internet usage by university academics: implications for the 21st century teaching and learning. International Journal of Science and Research, 2(9): 19-25. [Online]. https://www.ijsr.net/archive/v2i9/MjgwODEzMDE=.pdf (5 September 2017).

Tyagi, S. 2012. Awareness and use patterns of online journals and databases: a study of P.K. Kelkar Library at the Indian Institute of Technology Kanpur. Library Student Journal, January 2012 [Online]. http://www.librarystudentjournal.org/index.php/lsj/article/view/215/324 (17 July 2015).

Upadhyay, N. and Chakraborty, H. K. 2008. Online journals and databases: a case study of use and awareness among academics at Main Library, I.T., B.H.U. Paper presented at the 6th International CALIBER-2008, University of Allalabad, Allalabad. 28-29 February and 1 March 2008.

Vasishta, S. and Navivoti, A. 2011. Trends in the use of e-journals: a case study of PEC University of Technology, Chandigarh. Library Philosophy and Practice 2011. [Online]. http://www.webpages.uidaho.edu/ mbolin/vasishtanavivoti.htm (21 June 2016).

Veeramani, M. and Vinayagamoorthy, P. 2010. Impact of online journals among management graduates at Dubai International Academic City: a pragmatic study. International Journal of Library and Information Science, 2(2): 17-23, March 2010. [Online]. http://www.academicjournals.org/ijlis (17 August 2016).

Venkatesh, V., Morris, M. G., Davis, G. B. and Davis, F. D. 2003. User acceptance of information technology: towards a unified view. MIS Quarterly, 27(3): 425-478. [Online]. http://www.jstor.org/stable/30036540 (21 February 2016). 
Watts, C. and Ibegbulam, I. 2006. Access to electronic health care information resources in developing countries: experiences from the medical library, College of Medicine University of Nigeria. IFLA Journal, 32(54). [Online]. http://ifl.sagepub.com/content/32/1/54.full.pdf+html (04 August 2015). 